\title{
Development of Learning Management System-Based Blended Learning Model using Claroline in Higher Education
}

\author{
https://doi.org/10.3991/ijim.v14i06.13399 \\ Munir Tubagus $(\bowtie)$, Suyitno Muslim, Suriani \\ Jakarta State University, Jakarta, Indonesia \\ munirtubagus_tp14s3@mahasiswa.unj.ac.id
}

\begin{abstract}
Learning Management System (LMS) is a learning process that utilizes computer information technology equipped with internet and multimedia telecommunications facilities (graphics, audio, video) in delivering material and interaction between instructors and learners. The purpose of this study is to develop blended learning Using Claroline as a learning tool that facilitates students in learning. To achieve the objective of the study the research uses a quantitative approach to collect data using pre and post tests and questionnaires. The sample in the study were students of economic Islamic consisting of two classes, with a total of 50 students enrolled in this study. The results show that the difference in the average pre-test and post-test score was -29.43720 . While the t-test that tests Ho: $\mu_{\text {pre-test }=}^{\text {作 }} \mu_{\text {post-test gives a value of } \mathrm{t}=-37.43720}$ with a degree of freedom of 49 . While the p-value for the two-sided test of 0,000 is smaller than $\alpha=0.05$. This data approves that the statistical hypothesis Ho: $\mu_{\text {pre-test }=} \mu_{\text {post-test is rejected, meaning that the average pre-test and }}$ post-test scores are significantly different. The findings of this study can be used to recommend effective ways of learning and teaching using e-learning that can improve student learning outcomes in higher education. The implications of this research is to encourage teachers to use e-learning technology and facilitate students with the technology in improving academic learning outcomes.
\end{abstract}

Keywords-Learning Management System, Blended Learning, Claroline, Motivation

\section{$1 \quad$ Introduction}

The rapid development of information and communication technology (ICT) in the current era of globalization cannot avoid its influence on the world of Education. The demands of the global world urge the world of education to constantly adapt to technological developments, especially adaptation to the use of ICTs in the learning process. The progress of information technology has had a positive impact on the advancement of education today. Especially computer and internet technology, both in terms of hardware and software, provide many offers and choices for the world of 
education to support the learning process. The advantages offered not only lie in the speed factor for getting information but also multimedia facilities that can make learning more interesting, visual and interactive. Changes in the education system are the demands of a nation to have quality human resources. In line with the development of Information and Communication Technology (ICT) as can be seen in the e-learning based learning environment, each individual student has the freedom to determine what he wants to learn, where and how the learning process is carried out. In a learner centered learning environment, various facilities are provided in such a way that each individual student can actively build his own knowledge structure based on his own initiatives and responsibilities.

Through a learning environment supported by Information and Communication Technology (ICT), students have enormous access to abundant learning resources, receive feedback, and continually refine their understanding through a process known as generative learning. Lecturers as facilitators or moderators of their duties help students to want to learn on their own, formulate their understanding, evaluate the suitability of students' ideas with the ideas of experts. While the task of students is to actively learn and digest the knowledge provided, students can express ideas, criticize the opinions of lecturers which are considered inappropriate. Learning outcomes are actual abilities that can be measured directly, where the learning outcomes will later be known to what extent the educational and teaching goals that have been achieved. The learning outcome assessment process can provide information to the lecturer about the progress of students in an effort to achieve their learning goals through learning activities, then from that information later the lecturer can arrange and plan the process of further learning as an effort to realize better learning goals. The study "Student Characteristics and Learning Outcomes in a Blended Learning Environment Intervention in Ugandan University" found that the effect of blended learning on learning outcomes showed significant results. This shows that blended learning improves student learning outcomes. [1]

Research on "Evaluation of Blended Learning Approaches in Computer Engineering Education" Integrates face-to-face online and traditional learning in Algorithms and Programming courses at the Computer Engineering Department at Suleyman Demirel University, taught with blended learning methods. Achievement of the Learning Management System (LMS) at the university by using distance education technology in the flash animation course, the evaluation carried out has met the specified standards. Then analyze and compare student performance both with online learning and traditional learning or face to face. Showing results that are more effective, student achievement is better than expected compared to traditional face-to-face learning. The ability to think of student algorithms is better [2]. Referring to the results of the existing research, the blended learning learning model that combines faceto-face learning, with online learning learning shows an increase in students' comprehension skills in mastering learning material so that it can improve student learning achievement. For this reason, it is necessary to conduct research that can develop strategies or learning models that are an alternative to achieving effective learning goals. 


\section{Literature Review}

A literature review will be used to study different definitions of blended learning, the difference between a traditional, web facilitated, blended learning and online course; the implementation of a blended learning course in the process of learning English at National Research Tomsk Polytechnic University. Also the example of using the English course to teach engineering students will be provided. Allen and Seaman divide all courses into groups;

1. Traditional course which doesn't use online technologies. All the material is given orally or in pen

2. Web facilitated course user web-based technologies, For example, web pages are used to provide the syllabus and assignments (1-29\% of the material is given online)

3. Blended (hybrid) course combines online learning and face-to-face classes (30$79 \%$ is delivered online)

4. Online course implies that most of all the content (more than $80 \%$ ) is delivered online [3].

The potential for implementing learning with the blended learning system is very possible to implement, along with the development of information and communication technology. Book of "Preparing for Blended e-Learning" The combination of conventional teaching approaches and e-learning elements within a single course or programme is commonly referred to as 'blended learning', but we can also think of it as blended e-learning, the blend refers to the proportion of e-learning content within the course [4]. Next the basic principle of blended learning is that face-to-face oral communication and online written communication are optimally integrated such that the strengths of each are blended into a unique learning experience congruent with the context and intended educational purpose. [5]. Research Student Characteristics and Learning Outcomes in a Blended Learning Environment Intervention in a Ugandan University menemukan bahwa pengaruh pembelajaran blended learning terhadap hasil belajar menunjukan hasil yang signifikan. Hal ini menunjukan pembelajaran bleneded learning peningkatan hasil belajar mahasiswa. [1]. Research Development of blended learning model with virtual science laboratory for secendary students. The aim of this development study is to develop a blended learning model that uses project-based learning through virtual science laboratories in science classes for high school students. This model can improve students' ability to understand lessons more easily, and make it possible to conduct experiments as high as encouraging students to carry out further experiments. [6].

Based on the assumptions above, blended learning based learning is the best choice to increase effectiveness, efficiency, and greater attractiveness in interacting between humans in diverse learning environments. Blended learning offers learning opportunities to be good together and separate, as well as at the same time or different. A learning communication can be done by students and instructors who can interact at any time and anywhere because they use the use of computer and other devices (iPhone) 
as learning facilities. Based on the assumptions above, blended learning based learning is the best choice to increase effectiveness, efficiency, and greater attractiveness in interacting between humans in diverse learning environments. Blended learning offers learning opportunities to be good together and separate, as well as at the same time or different. A learning communication can be done by students and instructors who can interact at any time and anywhere because they use the use of computer and other devices (iPhone) as learning facilities. Blended learning has a number of advantages in comparison with traditional learning courses. One of the advantages of blended learning is that it is easily adaptable to learners' needs. The adaptability comes from different ways how online resources can be used. The most important component of blended learning is its flexible course. If the teacher notices any problems that the learners have while studying the course, he/she can immediately solve these problems by changing the material and learning activities. Learners' individual needs should be taken into consideration, otherwise even well-designed courses can fail. If the course is flexible it contributes to raising learners' motivation.

\section{Research Methodology}

The paper outlines the methodology for the Both qualitative and quantitative data were used together in this study, including pedagogical objectives, task design, selection of a blended course, as an educational tool and its implementation in the learning process. We use the following methods in our research: the analysis, the review of literature, observing our own professional experience with data analysis. The purpose of the study is to solve the problems that occur in learning by developing a blended based learning package in the management information system course, we've formulated the following pedagogical objectives:

1. Obtain an overview of the conceptual model of blended learning based on management information systems courses

2. Describe the procedural model of blended learning based management information systems courses

3. To evaluate the hypothesis that blended learning is an effective educational tool to learn and teach management information systems at the technical university

This research was conducted at the Manado State Islamic Institute (IAIN) in 2018. The first step in conducting a literature study included: summarizing, interpreting and evaluating the literature related to the subject of research in building a theoretical framework. The researcher modified the questionnaire before giving it to the respondent to answer, the number of respondents was 50 students consisting of 25 class $\mathrm{A}$ students and 25 class B students, which would be distributed to all respondents directly in their respective classes. Questionnaire data was collected within 2 weeks. After filling in the answers, all of them are collected for further data analysis by researchers to obtain results and findings from the development of blended learning models. All the data collected from the respondents were gathered together to be analyzed using Statistical Package for the Social Sciences (SPSS) version 21. The analysis includes 
both descriptive and inferential analysis. The researchers used descriptive analysis to analyze the frequency and percentage of the overall population in the demographic background. Besides, it is also used to determine the mean, standard deviation, frequency and percentage to identify the effectiveness development of blended learning models.

\subsection{Testing Requirements Analysis}

Table 1. Testing the Normality of Initial Value Data (Pre-test)

\begin{tabular}{|c|c|c|c|c|c|c|}
\hline Initial Value & Frekuensi & Fkomulatif & $\mathbf{Z}$ & $\mathbf{F}(\mathbf{Z})$ & $\mathbf{S}(\mathbf{Z})$ & $\mathbf{L}$ \\
\hline 29.97 & 1 & 1 & -2.0823389 & 0.0186558 & 0.02 & 0.0013442 \\
\hline 33.3 & 3 & 4 & -1.7431958 & 0.0406497 & 0.08 & 0.0393503 \\
\hline 36.63 & 2 & 6 & -1.4040526 & 0.0801516 & 0.12 & 0.0398484 \\
\hline 39.96 & 4 & 10 & -1.0649095 & 0.1434584 & 0.2 & 0.0565416 \\
\hline 43.29 & 5 & 15 & -0.7257663 & 0.233991 & 0.3 & 0.066009 \\
\hline 46.62 & 7 & 22 & -0.3866232 & 0.3495176 & 0.44 & 0.0904824 \\
\hline 49.95 & 6 & 28 & -0.04748 & 0.4810653 & 0.56 & 0.0789347 \\
\hline 53.28 & 4 & 32 & 0.2916631 & 0.6147279 & 0.64 & 0.0252721 \\
\hline 56.61 & 5 & 37 & 0.6308063 & 0.7359164 & 0.74 & 0.0040836 \\
\hline 59.94 & 3 & 40 & 0.9699494 & 0.8339641 & 0.8 & 0.0339641 \\
\hline 63.27 & 5 & 45 & 1.3090925 & 0.9047485 & 0.9 & 0.0047485 \\
\hline 66.6 & 4 & 49 & 1.6482357 & 0.9503478 & 0.98 & 0.0296522 \\
\hline 69.93 & 1 & 50 & 1.9873788 & 0.9765598 & 1 & 0.0234402 \\
\hline
\end{tabular}

\begin{tabular}{|l|c|}
\hline \multicolumn{1}{|c|}{ Average } & $\mathbf{5 0 . 4 1 6 2}$ \\
\hline Standard Deviation & 9.81886 \\
\hline Alpha & 0.05 \\
\hline L table & 0.12530 \\
\hline L count & 0.09048 \\
\hline
\end{tabular}

Based on the above calculations obtained $\mathrm{L}$ count $=0.09048$. At the real level $($ Alpha $)=0.05 \mathrm{n}=50$, the price of $\mathrm{L}$ table $=0.12530$. Because $\mathrm{L}$ count $=0.09048$, the initial value data (Pre-test) is normally distributed.

\section{$4 \quad$ Results and Findings}

Normality testing is the calculation of statistical data to test data whether it is continuously distributed normally or not, so hypothesis testing can be carried out. The normality testing technique uses the Lilliefors Test, the calculation and testing process is shown in the appendix.

The statistical hypothesis underlying normality testing is:

Ho: data is normally distributed

$\mathrm{H} 1$ : data is not normally distributed

Based on the hypothesis above, the criteria used are rejecting the null hypothesis, if the value of $\mathrm{L}$ count $>\mathrm{L}$ table at a significant rate $\alpha=0.05$, which means the data is from a population that is not normally distributed. Instead accept the null hypothesis, 
if the value of $\mathrm{L}$ count $<\mathrm{L}$ table at a significant level $\alpha=0.05$, which means the data is from a population that is normally distributed.

\subsection{Normality of pre-test data}

The initial value data (pre-test) is student value data before being taught using the blended learning. Based on the results of the Microsoft Excel application, it is known that the average pretest value is 50.41 and the standard deviation value (si) is 9.8188 . Next is to determine the normal cumulative probability $\mathrm{F}$ (zi) and the cumulative probability of impulse S (zi), based on the results of the normal cumulative probability and the large probability is $\mathrm{L}$ count $=0.9048$. Sample $=50$ and significance level $\alpha$ $=0.05$. L table $=x=0.12530 /(\sqrt{50})=0.12530$. The calculation results show that a significant level of $0.05 \mathrm{~L}$ count $<\mathrm{L}$ table $(0.09048<0.12530)$ which means accepting the null hypothesis. The conclusion of the pre-test data is that it comes from a population that is normally distributed

\subsection{Normality of post-test data}

The final value data (post-test) is student value data after being taught using the blended learning. Based on the results of the Microsoft Excel application count, it is known that the average value post-test is 79.99 and the standard deviation value (si) is 8.83574. Next, determine the normal cumulative probability F (zi) and the cumulative impulse probability $\mathrm{S}$ (zi), based on the results of the normal cumulative probability and the cumulative probability of the student's post-test results obtained the highest price is $\mathrm{L}$ count $=0.11675$. Sample $=50$ and significance level $\alpha=0.05$. $\mathrm{L}$ table $=\mathrm{x}=$ $0.886 /(\sqrt{50})=0.12530$. The calculation results show that at a significant level of $0.05 \mathrm{~L}$ count $<\mathrm{L}$ table $(0.11675<0.12530)$ which means accepting the null hypothesis. The conclusion of the pre-test data is that it comes from a population that is normally.

\subsection{Data homogeneity test}

Testing the sample data that has been proven to be normally distributed, then further testing of the homogeneity of the variance of the two samples is carried out. Homogeneity testing techniques using the Barrett Test, the calculation process and testing are attached. The statistical hypothesis underlying homogeneity testing is:

Ho: homogeneous sample data

H1: sample data is not homogeneous

Based on the hypothesis above, the criteria used are rejecting the null hypothesis, if the value of $x^{2}$ count $>x^{2}$ table at a significant level $\alpha=0.05$, which means the sample data is not homogeneous. Instead accept the null hypothesis, if the value of $x^{2}$ count $<\mathrm{x}^{2}$ table at a significant level $\alpha=0.05$, which means the sample data is homogeneous. Based on the results of the Microsoft Excel application count, the sample combined variance $=1.89762$ and unit price $\mathrm{B}=21.7000$, and the value of $\mathrm{x}^{2}$ count $=$ 290,839 , the value of $x^{2}$ table at a significant level $\alpha=0.05$ is 3.841 . So $x^{2}$ count $=$ - 
$290,839<x^{2}$ table $=3,841$, so it can be concluded that Ho is accepted which means the sample data is homogeneous.

\subsection{T test (paired t-test)}

The implementation of the model is to see how the effectiveness of the blended learning the Management Information System course. he effectiveness of the product model developed is calculated through analysis using SPSS which produces the following information:

Table 2. Results of the SPSS Program Calculation Process.

\begin{tabular}{|c|c|c|c|c|c|c|c|c|}
\hline \multicolumn{9}{|c|}{ Paired Samples Test } \\
\hline & \multicolumn{5}{|c|}{ Paired Differences } & \multirow[t]{3}{*}{$t$} & \multirow[t]{3}{*}{$d f$} & \multirow{3}{*}{$\begin{array}{l}\text { Sig. }(2- \\
\text { tailed })\end{array}$} \\
\hline & \multirow[t]{2}{*}{ Mean } & \multirow[t]{2}{*}{\begin{tabular}{|c|} 
Std. Devia- \\
tion
\end{tabular}} & \multirow{2}{*}{$\begin{array}{c}\text { Std. } \\
\text { Error } \\
\text { Mean }\end{array}$} & \multicolumn{2}{|c|}{$\begin{array}{l}95 \% \text { Confidence Inter- } \\
\text { val of the Difference }\end{array}$} & & & \\
\hline & & & & Lower & Upper & & & \\
\hline \begin{tabular}{l|l} 
Pair 1 & $\begin{array}{l}\text { Pre test - } \\
\text { Post test }\end{array}$
\end{tabular} & -29.43720 & 5.52157 & .78087 & -31.00641 & -27.86799 & -37.698 & 49 & .000 \\
\hline
\end{tabular}

\begin{tabular}{|l|c|c|c|c|c|}
\hline \multicolumn{6}{|c|}{ Paired Samples Statistics } \\
\hline \multicolumn{2}{|c|}{} & Mean & $\boldsymbol{N}$ & Std. Deviation & Std. Error Mean \\
\hline \multirow{2}{*}{ Pair 1 } & Pre test & 50.4162 & 50 & 9.81886 & 1.38860 \\
\cline { 2 - 6 } & Post test & 79.8534 & 50 & 8.81010 & 1.24594 \\
\hline
\end{tabular}

\begin{tabular}{|l|l|c|c|c|}
\hline \multicolumn{5}{|c|}{ Paired Samples Correlations } \\
\hline \multicolumn{7}{|c|}{} & $\boldsymbol{N}$ & Correlation & Sig. \\
\hline Pair 1 & Pre test \& Post test & 50 & .830 & .000 \\
\hline
\end{tabular}

The data above shows that the mean score of the pre-test and post-test score is 29.43720. While the t-test that tests Ho: $\mu_{\text {pre-test }=} \mu_{\text {post-test gives a value of } \mathrm{t}=}$ -37.43720 with 49 degrees of freedom. While the p-value for the two-tailed (2-tailed) test is 0.000 which is smaller than $\alpha=0,05$. This data proves that the statistical hypothesis Ho: $\mu_{\text {pre-test }}=\mu_{\text {post-test is rejected. The conclusion that can be drawn is }}$ that the mean score of the pre-test and post-test are significantly different. The data above also shows the correlation of the two variables at $r=0.830$ and hypothesis test data to determine the significance of the correlation $\mathrm{p}$-value $=0.000$. In this case, $\mathrm{p}$ value $=0,000$ is smaller than $\alpha=0.05$, so pearson correlation is significant.

Based on the above data analysis it can be concluded that the average score of the pre-test and post-test is different, and the difference is significant. This means that the product of the blended learning package in the Management Information System used by students is effective, because it produces meaningful learning outcomes for students. The findings of this study can be used to recommend effective ways of learning and teaching using e-learning so that it can improve student learning outcomes in higher education. The implications of this research recommendation are to encourage 
them to use e-learning technology and facilitate students in improving academic learning outcomes.

\section{Conclusion}

The results of the research and data analysis obtained from the evaluation during the development process of blended learning products in the Management Information Systems course are

1. The process of research and development carried out has produced a product of the blended learning in the Management Information System course. This product consists of procedural models and physical models. The procedural model is the result of the construction of the theoretical study which is manifested in the form of images. The procedural model that was successfully developed consisted of the steps to develop a blended learning tool in the Management Information System course. Whereas physical products are manifested in the form of programs (systems) for blended learning based on learning management systems (LMS) which are equipped with learning tools such as syllabus, lesson plans, compilation of teaching materials, and evaluation systems.

2. Development of field testing to determine the effectiveness of the product of blended learning development in the Management Information Systems course. The effectiveness test is done by testing the normality of the initial test data (pretest) with the results of calculations that show that at a significant level of $0.05 \mathrm{~L}$ count $<$ L count $<$ L table $(0.96191<0.14010)$ which means accepting the null hypothesis. Conclusion of the pre-test data is derived from a population that is normally distributed. The final test data (post-test) with the calculation results shows that at a significant level of $0.05 \mathrm{~L}$ count $<\mathrm{L}$ table $(0.107363<0.14019)$ which means accepting the null hypothesis. Conclusion of the pre-test data is derived from a population that is normally distributed.

3. Test homogeneity of data seen at the significance level of $=0.05$ obtained $x^{2}$ table $=3,841$, then $x^{2}$ count $=-290,839<x^{2}$ table $=3,841$, so it can be concluded that $H_{0}$ received means homogeneous data. And the effectiveness of the data test is done by analyzing the mean score of the results of the pre-test and post-test using the SPSS program. Based on the data about the opinions and ratings of students on the blended learning model they follow, it can be concluded that the mean score of the pre-test and post-test is not significantly different. This data shows the correlation of these two variables at $r=0.815$ and hypothesis test data to determine the significance of the correlation $\mathrm{p}$-value $=0.000$. In this case, $\mathrm{p}$-value $=0,000$ is smaller than $\alpha=0.05$, so person correlation is significant.

4. The right learning innovation will arouse the independence and confidence of students who have tried to find and explore learning resources not only from the teacher. It is this assumption that delivers blended learning to become an option when learning is not enough just face to face. Students get the opportunity to develop communication skills both in class and outside the classroom through online interaction with each other sambal discussing problems Together, for 
teachers can optimize the learning model in improving student learning independence, especially management information systems.

\section{References}

[1] M. J. Kintu and C. Zhu, "Student Characteristics and Learning Outcomes in a Blended Learning Environment Intervention in a Ugandan University.," Electron. J. e-Learning, vol. 14, no. 3, pp. 181-195, 2016.

[2] T. Yigit, A. Koyun, A. S. Yuksel, and I. A. Cankaya, "Evaluation of blended learning approach in computer engineering education," Procedia-Social Behav. Sci., vol. 141, pp. 807-812, 2014. https://doi.org/10.1016/j.sbspro.2014.05.140

[3] I. E. Allen and J. Seaman, Changing course: Ten years of tracking online education in the United States. ERIC, 2013.

[4] A. Littlejohn and C. Pegler, Preparing for blended e-learning. Routledge, 2007.

[5] D. R. Garrison and N. D. Vaughan, Blended learning in higher education: Framework, principles, and guidelines. John Wiley \& Sons, 2008.

[6] U. Klentien and W. Wannasawade, "Development of blended learning model with virtual science laboratory for secondary students," Procedia-Social Behav. Sci., vol. 217, pp. 706711, 2016. https://doi.org/10.1016/j.sbspro.2016.02.126

\section{Authors}

Munir Tubagus is currently Student, Department of Education Technology, Jakarta State University, Jakarta, Indonesia. Author is working and interested in learning management system. For contact matrix.bagus@ gmail.com

Suyitno Muslim is a Lecturer in, Department of Education Technology, Jakarta State University, Jakarta, Indonesia. Suyitno Muslim is working on learning management system and education technologies.

Suriani a Lecturer in Department of Education Technology, Jakarta State University, Jakarta, Indonesia. Author is working and interested in learning management system

Article submitted 2020-01-24. Resubmitted 2020-02-26. Final acceptance 2020-02-26. Final version published as submitted by the authors. 